\title{
Inflammatory Regulators of Redirected Neural Migration in the Injured Brain
}

\author{
Nicole Bye ${ }^{a, b}$ Ann M. Turnley ${ }^{c}$ M. Cristina Morganti-Kossmanna, ${ }^{a}$ \\ ${ }^{a}$ National Trauma Research Institute, Alfred Hospital, b Department of Surgery, Monash University, and \\ ${ }^{c}$ Centre for Neuroscience, Melbourne Brain Centre, University of Melbourne, Melbourne, Vic., Australia
}

\section{Key Words}

Adult neurogenesis $\cdot$ Brain injuries $\cdot$ Cell migration •

Chemokines $\cdot$ Growth factors · Inflammation •

Neural precursor cells

\begin{abstract}
Brain injury following stroke or trauma induces the migration of neuroblasts derived from subventricular zone neural precursor cells (NPCs) towards the damaged tissue, where they then have the potential to contribute to repair. Enhancing the recruitment of new cells thus presents an enticing prospect for the development of new therapeutic approaches to treat brain injury; to this end, an understanding of the factors regulating this process is required. During the neuroinflammatory response to ischemic and traumatic brain injuries, a plethora of pro- and anti-inflammatory cytokines, chemokines and growth factors are released in the damaged tissue, and recent work indicates that a variety of these are able to influence injury-induced migration. In this review, we will discuss the contribution of specific chemokines and growth factors towards stimulating NPC migration in the injured brain.
\end{abstract}

\section{Introduction}

With the discovery of neural stem and progenitor cells (collectively termed adult neural precursor cells, NPCs) in the adult mammalian brain, there have been significant efforts to elucidate the mechanisms that regulate the complex, multistaged process of neurogenesis, as well as investigation into its potential enhancement for the treatment of various neuropathologies. Neurogenesis is defined as the proliferation, migration, differentiation, maturation and survival of NPCs localized in specific brain regions. Endogenous precursor populations in adulthood are primarily confined to the subventricular zone (SVZ) surrounding the lateral ventricle, and the subgranular zone of the hippocampal dentate gyrus. The progeny gives rise to immature neuroblasts that migrate to the olfactory bulb and dentate gyrus granule cell layer for SVZ and subgranular zone precursors, respectively, where they mature into the appropriate neuronal subtype and integrate within existing neural networks [1-4].

Intriguingly, the proliferation of NPCs in the SVZ is enhanced in response to acute insults such as ischemia, trauma and neurotoxic lesions, as well as chronic neurodegenerative diseases [for reviews, see 5-8]. Importantly, these cells have the capacity to migrate to the injured brain region, differentiate into the neuronal phenotype specific to the area [9-11] and establish appropriate long- 
distance connections [11]. However, the ability of proliferating NPCs to replace lost neurons is limited, since only few precursors differentiate into neurons, and most of the new neurons die shortly after generation $[9,12]$. These recent findings underscore the need for a better understanding of injury-induced neurogenesis and suggest that manipulation of endogenous NPCs may become a potential strategy to promote brain reparative processes. To date, most studies in this field have examined mechanisms underlying NPC proliferation and neuronal differentiation after injury, whereas factors regulating enhanced migratory capacity and recruitment of neuroblasts to the site of brain damage are less well elucidated.

In the normal adult brain, the factors underlying migration of NPCs from the SVZ along the rostral migratory stream (RMS) are becoming evident. This long-distance migration involves regulation of various cellular processes, including cell adhesion, competency to migrate and ability to respond to directional signals. Directional cues are provided by a variety of chemorepulsive and chemoattractive factors arising from the lateral ventricle and brain parenchyma, or from the olfactory bulb and RMS astrocytes, respectively [for recent reviews, see 13, 14]. After brain injury, some mechanisms of NPC migration are similar to those occurring under physiological conditions, particularly in regard to signaling pathways that regulate cytoskeletal machinery to produce migration [14]; however, it is apparent that additional injury-induced factors are necessary to enable neuroblasts to exit the SVZ/RMS and redirect their migration towards remote damaged regions. Amongst the myriad of molecules released in damaged brain tissue, some candidates potentially regulating the migration of NPCs and their neuroblast progeny consist of specific immune mediators upregulated during the inflammatory response elicited after injury, as well as growth factors. In this review, we provide an overview of an array of chemotactic cytokines, or chemokines, and growth factors that are released following ischemic and traumatic brain injuries and their capacity to stimulate the ectopic migration of SVZ NPCs.

\section{Capacity for Redirected Migration of NPCs following Brain Injury}

\section{Focal Ischemia}

Injury-induced neurogenesis has been most thoroughly investigated to date in models of focal cerebral ischemia, and the mechanisms of stimulated prolifera- tion, migration, neuronal differentiation and survival are beginning to be elucidated [for recent reviews, see 5, $6,15]$. Focal ischemia occurs when blood flow to a specific brain region is interrupted, resulting in a discrete area of necrotic brain tissue surrounded by a hypoperfused penumbral region where at later stages vulnerable neural cells die. The most common experimental model of focal cerebral ischemia is transient middle cerebral artery occlusion (MCAO), which induces extensive damage to the striatum and cortex. Following MCAO, an early dramatic increase in SVZ precursor proliferation was demonstrated that persisted for at least 4 months $[9,12$, 16]. This stimulated proliferation was matched by redirected migration of vast numbers of neuroblasts from the SVZ to the injured striatum $[9,12,17-19]$. The origin of NPCs migrating to the striatum after MCAO was identified by labeling SVZ cells prior to injury with lipophilic dye [17] or with transgenic expression of green fluorescent protein [19], and both studies confirmed that following ischemia labeled SVZ cells migrated to the adjacent lesioned striatum. Yamashita et al. [19] further demonstrated that SVZ-derived neuroblasts differentiated into mature neurons and formed synaptic connections in the striatum, apparently contributing to brain repair. This redirected migration of NPCs from the SVZ to the site of injury can occur via multiple routes, including along blood vessels or astrocyte chains $[16,19,20]$, although the molecules responsible for this guidance are not yet fully elucidated.

\section{Traumatic Brain Injury}

Abundant recent studies have begun to characterize the neurogenic response following experimental models of traumatic brain injury (TBI). These studies have mostly utilized the lateral fluid percussion injury (FPI) and controlled cortical impact (CCI) modes of focal TBI in rats and mice. Lateral FPI is a form of focal injury that induces a unilateral cortical lesion and also includes a robust diffuse axonal injury component, and is produced by a global displacement of the brain by a fluid pulse [for a review, see 21]. Conversely, CCI is produced by a controlled, focal deformation of the brain by a metal piston and results in localized cell death and an extensive contusion cavity. In addition, a few very recent studies have also examined neurogenesis in a closed head injury weight drop model that causes a unilateral skull fracture with an underlying cortical contusion [21]. Following CCI, increased cellular proliferation was reported in the hippocampus and cortex, with new cells distributed around the lesion up to 60 days after injury $[9,22-25]$. These prolif- 
erating cells subsequently colocalized predominantly with markers of immature and mature neurons in the hippocampus, but in the pericontusional cortex, most new cells were identified as astrocytes and oligodendrocytes $[9,23,26]$. Similar to the CCI model, following lateral FPI, a significant increase in cell proliferation was seen in both the hippocampus and the SVZ within the first week after injury, with the majority of these cells colocalizing with markers of astrocytes and microglia [2729]. Cellular proliferation was shown to persist for 1 year after FPI with many of these cells acquiring astrocytic or immature neuronal phenotypes [30]. In the closed head injury model, a similar enhancement in hippocampal and SVZ proliferation was described within the first week after trauma, with the new cells surviving in the cortex for up to 90 days acquiring a glial phenotype [31; Bye et al., unpubl. data].

In comparison to the studies mentioned on experimental ischemia, the migration of NPCs from the SVZ to regions of tissue damage is less well characterized following traumatic injury, and little is known about the regulatory mechanisms involved. A few studies have definitively shown that SVZ NPCs migrate to the pericontusional cortex: following either retroviral labeling or incorporation of fluorescent microspheres or dye, large numbers of SVZ cells were identified within the pericontusional cortex from 3 days to 3 weeks following injury $[24,26,32]$. At earlier time points, some of the SVZ cells were colabeled with doublecortin (DCX; a microtubuleassociated protein expressed by NPCs and immature neurons), suggesting that at least a proportion of the cells were migrating neuroblasts, while at later times the majority of cells expressed glial markers. More recently, numerous studies have shown the presence of DCX-labeled neuroblasts in the pericontusional cortex from 1 to 90 days after TBI, which are proposed to have migrated from the SVZ [31, 33, 34; Bye et al., unpubl. data]. These reports clearly demonstrate the ongoing nature of this process, which is robust initially but diminishes over time. Furthermore, Itoh et al. [33] reported that a proportion of the DCX-labeled cells coexpressed the mature neuronal marker $\mathrm{NeuN}$ at 30 days, confirming that some neuroblasts may indeed survive to generate new neurons in the pericontusional cortex. Interestingly, some data suggest that neurogenesis after experimental trauma is associated with angiogenesis [31, 34]; however, evidence of neuroblasts using new blood vessels as migratory guides, as seen after ischemic damage, remains to be explored following TBI.

\section{Injury-Induced Factors Mediating Redirected Migration to Damaged Brain Regions}

The pathophysiology of brain injury after ischemic or traumatic insults is complex, and although distinct, both injury types elicit a similar neuroinflammatory response. This multifaceted reaction comprises both cellular and molecular pathways involving directly the brain parenchyma and indirectly the contribution of peripheral immune cells. As a result of injury, the disruption of the blood-brain barrier permits the transmigration of leukocytes, including neutrophils and macrophages, from the systemic circulation, coincident with the activation of resident glial cells, the astrocytes and microglia. Both infiltrating peripheral immune cells and activated glia engage in the synthesis and release of numerous pro- and anti-inflammatory cytokines, chemokines, neurotransmitters and reactive oxygen and nitrogen species. These factors further disrupt the blood-brain barrier, sustaining the recruitment and activation of leukocytes and glia, thus creating a positive feedback loop which prolongs inflammation and contributes to ongoing neuronal damage [35-37]. It is becoming increasingly clear that a mongst the plethora of factors released by activated glia, many are involved in regulating the neurogenic response after injury by mediating different neurogenic stages, including proliferation, neuronal differentiation and survival [for recent reviews, see 38-40]. More specifically, a number of chemokines and growth factors have recently been identified as necessary signals to stimulate the migration of SVZ NPCs and recruit neuroblasts to the damaged region; such factors are the focus of this review and will be discussed in detail below.

\section{Activated Microglia and Reactive Astrocytes Regulate}

Neurogenesis after Injury

As part of the brain's innate inflammatory response to brain injury, microglia are rapidly activated and recruited to the damaged site, where they release numerous proand anti-inflammatory cytokines, chemokines and reactive nitrogen and oxygen species, but also a significant number of growth factors [41]. Early work investigating the contribution of activated microglia to injury-induced neurogenesis found a primarily deleterious role for these cells, in that inhibition of microglial activation by antiinflammatory treatment with minocycline and indomethacin resulted in enhanced hippocampal neurogenesis in models of cranial irradiation, epilepsy and ischemic stroke [42-45]. Interestingly, such pharmacological approaches were associated with improved functional 
outcome [44]. However, recent studies have begun to reveal rather a dual role of activated microglia, which display a complex, multifaceted impact on injury-induced neurogenesis with both supportive and detrimental actions. While microglia-derived factors may stimulate the early stages of neurogenesis, their ultimate consequence may be to create an environment that is detrimental to the long-term survival of new neurons. Moreover, specific effects on neurogenesis may be dependent upon the degree of microglial activation, with robustly activated microglia being inhibitory, and more mildly activated microglia being supportive, and these diverse characteristics may be linked to the soluble factors that are selectively released [for reviews, see 38-40]. For example, the proinflammatory cytokines expressed by acutely activated microglia following lipopolysaccharide or interleukin (IL)-6 stimulation or during status epilepticus, including IL-1 $\beta$, IL-6, IL-18, $\gamma$-interferon and tumor necrosis factor (TNF) $\alpha$, have been shown to specifically inhibit precursor proliferation, neuronal differentiation or survival of new neurons [42, 46-49]. Conversely, microglia activated via an adaptive immunity response to low levels of the cytokine $\gamma$-interferon can instruct neuronal differentiation and survival [50]. In addition to cytokines, activated microglia in the injured brain also produce multiple chemokines, including CXCL12 and CCL2, and growth factors, such as brain-derived neurotrophic factor (BDNF) and epidermal growth factor (EGF) [41], which in turn have been shown to promote multiple neurogenic stages, including precursor proliferation, neuronal differentiation and survival, as well as the redirected migration of neuroblasts to the damaged brain region [51-54].

In addition to microglia, astrocytes are pivotal in regulating injury-induced neuroinflammation [for reviews, see 55,56$]$. In a rapid response to injury, astrocytes undergo reactive astrogliosis, involving cell proliferation, hypertrophy and increased expression of glial fibrillary acidic protein [56]. Similar to activated microglia, reactive astrocytes release a wide variety of cytokines, such as TNF $\alpha$, IL-1 $\beta$, IL- 6 and IL-10, as well as growth factors, such as BDNF, basic fibroblast growth factor (FGF2) and vascular endothelial growth factor (VEGF) [56], which can have both negative and positive effects on neurogenesis. Thus, astrocytes are also likely to be important in regulating injury-induced neurogenesis. In support of this concept, in vitro experiments have shown that astrocytes cocultured with adult rat NPCs stimulate their proliferation and neuronal differentiation [57]; however, the specific ability of astrocytes to regulate NPC migration after injury remains unexplored.

Regulation of Injury-Induced NPC

Migration

\section{Chemokines}

Chemokines form a family of small $(8-14 \mathrm{kDa})$, mainly basic, secreted molecules that are primarily known for regulating chemoattraction of immune cells to sites of inflammation and tissue damage. The family is divided into 4 groups based on the relative position of the first N-terminal cysteine, with multiple members called ligands (L) in each group (CCL, CXCL, CX3CL and CL) $[58,59]$. They bind to and signal through heterotrimeric G-protein-coupled 7-transmembrane domain receptors $(\mathrm{R})$ named after each respective ligand family: CCR, CXCR, CX3CR, CR.

While most research on chemokines has focused on systemic inflammatory diseases, numerous studies have also shown that chemokines play multiple roles within the nervous system. They have widespread nonimmunological effects in the central nervous system (CNS), including regulation of neural cell proliferation, migration, survival and synaptic transmission and can act in a paracrine or autocrine manner $[58,60]$. Chemokines and their receptors are constitutively expressed during development of the CNS, and their expression persists in the adult brain restricted to specific regions. To date most work on chemokines in the CNS has focused on their impact on NPCs, and both embryonic and adult mouse NPCs express most chemokine receptors in culture [61, 62] and some chemokines [62]. Human embryonic NPCs have also been reported to express the chemokine receptors CCR 3 and CXCR4 $[63,64]$. The pattern of expression of chemokines and their receptors in NPCs coincides with the pattern identified in the normal adult mouse brain, where almost all chemokine receptors and most CXC chemokines have been detected in the olfactory bulb at the highest levels, with variable levels of receptor expression in the other neurogenic regions, the SVZ and hippocampus. On the other hand, nonneurogenic regions of the brain, such as the cortex, constitutively express very few of the chemokine receptors and at low levels [62]. The abundant expression in the olfactory bulb suggests that multiple chemokines and their receptors may play a role in regulating the migration of NPCs to and within the olfactory bulb under normal conditions.

Following neural injury or inflammatory disease, the production of many chemokines is induced or enhanced in the CNS, including CCL2, CCL3, CXCL1, CXCL5, CCL12 and CXCL10 [65-69]. Expression of other chemokines, including CCL19, CCL21 and CXCL13, is primarily found on infiltrating immune cells or endothelial cells rather than on CNS parenchymal cells [70]. As major mediators of cerebral inflammation, a primary role of chemokines is to attract leukocytes to the injured tissue.

Neurosignals 2012;20:132-146 
However, as discussed below, they may also be important for the recruitment of NPCs to regions of damaged brain tissue after injury.

\section{The Chemokine CXCL12}

Most studies exploring the role of chemokines in the nervous system have centered on the macrophage-attracting chemokine CXCL12 (or stromal-derived factor $1 \alpha$ ), since it is the most widespread and highly expressed chemokine in the CNS. Not only is CXCL12 with its receptor CXCR4 expressed in neurogenic brain regions, it is also expressed in nonneurogenic regions, such as the cortex, indicating that this chemokine functions not only in NPC migration, but also in normal adult parenchymal physiology [62, 71-76]. CXCL12 also has multiple roles in neural development. It modulates the proliferation of embryonic NPCs in an EGF/FGF2-dependent manner [77] but is better known for regulating precursor cell migration in various nervous system regions, such as the cerebellum $[60,78,79]$ and neural crest $[73,80]$, as well as in radial glial cells [81].

CXCL12 has also been the most widely studied chemokine with respect to NPC migration in the adult brain. The CXCL12/CXCR4 ligand/receptor pair promotes NPC migration in vitro $[64,82-84]$ in a phosphoinositol-3-kinase-dependent manner [85]. Moreover, in vivo studies showed that CXCL12/CXCR4 regulates the migration of NPCs of the SVZ in adult rodent brain [86], with further work suggesting that CXCR7, an alternate CXCL12 receptor, is also involved in this process [87].

In the pathological adult brain, expression of CXCL12 is increased after ischemia [16, 52, 88-90] and TBI [91], predominantly by reactive astrocytes, activated microglia and endothelial cells. Evidence suggests that CXCL12 contributes to the endogenous NPC response to damage by directing their migration to the site of injury $[16,52$, $92,93]$. Similarly, CXCL12 also promoted the mobility [93] and directed migration $[16,52,92,93]$ of neuroblasts derived from human or rodent NPCs that were transplanted into ischemic brain.

\section{The Chemokine CCL2}

The chemokine system of CCL2 (or monocyte chemoattractant protein 1) and its receptor CCR2 plays a crucial role in mediating monocyte, macrophage and microglial migration into the CNS under neuroinflammatory conditions [for a review, see 59]. CCL2 is acutely increased within the first hours in rodent models of ischemic stroke [54, 94, 95] and TBI [96-98], being predominantly produced by astrocytes, resident microglia and in- filtrating macrophages, and to a lesser extent by endothelial cells and neurons.

CCL2 has recently been identified as an important chemotactic factor for NPCs, which express CCR2 [61, 67]. In vitro chemotaxis assays using NPCs isolated from the SVZ of postnatal and adult rodents have shown that NPCs migrate in response to CCL2 [54, 67, 84, 92, 99]. Similarly, implanted NPCs and resident SVZ neuroblasts were recruited toward sites of recombinant CCL2 infusion into the brain in vivo $[54,100]$.

CCL2 appears to be an important inflammatory factor playing a role in neuroblast migration also in the pathological brain. When NPCs were transplanted into hippocampal brain slices cultured from CCL2 or CCR2 knockout mice, they failed to migrate towards an inflammatory stimulus [101]. In ischemic brain in vivo, CCL2dependent migration of neuroblasts to sites of tissue damage was also demonstrated using CCL2- or CCR2deficient mice [54]. Our group recently observed a similar effect of CCL2 on neuroblast migration following experimental TBI: using a mouse model in which CCL2 greatly increases in the injured cortical tissue [98], we found that the number of DCX-positive cells migrating from the SVZ to the pericontusional cortex was reduced by approximately $40 \%$ in mice deficient for CCL 2 compared to wild-type controls [Bye et al., unpubl. data], thus corroborating the important role of this chemokine in traumainduced migration of neuroblasts to the lesioned cortex.

\section{Other Chemokines}

Although less intensely investigated, other chemokines have also been shown to affect NPC migration. It was demonstrated that CXCL16 regulates migration of a glial precursor cell line [102] and CXCL8 and CXCL13 mediated NPC migration across endothelial cells in culture [103]. Additionally, CXCL1 has been shown to be a potent chemoattractant for cultured NPCs $[67,104]$, while CCL3 and CXCL1 promote NPC migration following striatal cell loss [67]. The mechanisms by which chemokines promote the migration of cell types that migrate collectively with cell-cell contact, such as NPCs, are beginning to be elucidated and seem to involve the stabilization of cell protrusions at the forward edge of the polarized cells, resulting in directional migration [105].

Given that many other chemokines and their receptors are differentially expressed in distinct neurogenic regions of the CNS [62], it is conceivable that individual chemokines exert region-specific effects. For example, in the normal adult mouse brain CXCL1 is highly expressed in the adult hippocampus but is found at lower levels in 
the SVZ and olfactory bulb, whereas CXCL5 is abundant in the olfactory bulb and SVZ but low in the hippocampus [62]. However, despite its low constitutive expression, CXCL1 is upregulated in cultured SVZ-derived NPCs after stimulation by $\mathrm{TNF} \alpha$. Together, these data suggest that CXCL1 may have a physiological role in the hippocampus and an inflammation-related role in the other neurogenic regions. Whether or not other chemokines may regulate the migration of NPCs or have other nonmigratory functions remains to be determined.

\section{Growth Factors}

Growth factors are proteins that modulate cell proliferation, differentiation and survival. It is well established that many, such as the neurotrophins, are critical for the developing and adult nervous system, while more recently, others, including hematopoietic growth factors, have been found to also influence neurogenesis. A wide variety of growth factors are released after brain injury, with their production being attributed to activated microglia, reactive astrocytes, endothelial cells and neurons [for reviews, see 35,106$]$. It has become increasingly apparent that growth factors are important in stimulating injuryinduced neurogenesis. In particular, a number have been recently implicated in mediating NPC migration in the damaged brain, including erythropoietin (EPO), VEGF, granulocyte colony-stimulating factor (G-CSF), BDNF, FGF2 and EGF, as discussed in detail below.

Erythropoietin

EPO is a major hematopoietic cytokine with multiple neuroprotective functions in neuropathology [107]. In the adult brain, EPO and its specific receptor EPOR are expressed by neurons, astrocytes and capillary endothelial cells [108]. EPOR also colocalizes with NPCs in the adult SVZ [109], implying a possible role in neurogenesis. In fact, robust evidence suggests that EPO and EPOR modulate embryonic and adult neurogenesis, particularly by enhancing precursor cell proliferation and the subsequent production of neuronal-lineage restricted progenitors [109-111]. In addition, studies are beginning to identify a specific role for EPO/EPOR in NPC migration in normal adult brain. Infusion of rhEPO into the lateral ventricle of adult naive mice increased the migration of SVZ progenitors towards the olfactory bulb, leading to a net gain in new interneurons, while administration of an anti-EPO neutralizing antibody significantly decreased the number of newly generated migrating cells, demonstrating that both exogenous and endogenous EPO can regulate neuroblast migration [109].

Regulation of Injury-Induced NPC

Migration
The expression of EPO and EPOR in the brain increased in response to injury in patients $[112,113]$ as well as in models of ischemia [114] and TBI [115], suggesting that endogenous EPO may contribute to injury-induced repair. In fact, using conditional EpoR knockdown mice, Tsai et al. [111] showed that brain-specific deletion of $E p o R$ leads to a decrease in poststroke neurogenesis, in part due to impaired migration of neuroblasts to the periinfarct cortex. In addition, treatment with rhEPO enhanced injury-induced neurogenesis after experimental stroke and TBI by stimulating the migration of SVZ precursors to the peri-infarct/contusional region [116-119]. The beneficial effects of rhEPO on postischemic progenitor migration are potentially mediated via matrix metalloproteinase 2 and 9 secretion via the phosphoinositol-3kinase/Akt1 and ERK1/2 signaling pathways [120].

\section{Vascular Endothelial Growth Factor}

Another pivotal hematopoietic growth factor with recently discovered roles in neurogenesis is VEGF. VEGF is a major angiogenic mediator that promotes proliferation and survival of endothelial cells [121]. It also acts as a guidance cue for endothelial progenitors and hematopoietic cells $[122,123]$. Recently, neurotrophic and neuroprotective properties of VEGF have been identified in the CNS $[124,125]$, with the VEGFR2 receptor (KDR/Flk1) apparently mediating most neuron-specific effects [126, 127]. The expression of VEGFR1 (Flt1) and VEGFR2 (KDR/Flk1) receptors has been identified on SVZ progenitors isolated from neonatal rat brain and cultured in the presence of FGF2 [128]. In the adult rodent brain, VEGF has been shown to mediate the neurogenic effects stimulated by exercise and an enriched environment on production of new hippocampal neurons [129]. In addition, intraventricular infusion of VEGF led to increased cell proliferation in the SVZ $[130,131]$. Abundant evidence also supports the ability of VEGF to instruct the migration of SVZ neuroblasts, with mice lacking VEGF showing significant impairment in SVZ neurogenesis with fewer cells reaching the olfactory bulb [131]. Additionally, the release of VEGF from astrocytes induced proliferation and migration of SVZ neuroblasts towards the olfactory bulb in vivo, via stimulation of VEGFR1 [132]. In vitro studies using chemotaxis assays have further demonstrated that VEGF is an attractive guidance cue for the migration of undifferentiated NPCs isolated from neonatal rat SVZ [128] and cortex [133], and that this effect is mediated via VEGFR2 but not VEGFR1 [128]. 
VEGF is expressed in the CNS after experimental trauma and stroke [134-136] and has important implications in mediating ectopic migration of SVZ neuroblasts to the site of injury. Wang et al. [137] showed that VEGFoverexpressing mice had enhanced SVZ cell proliferation after permanent focal cerebral ischemia, with chains of migratory neuroblasts extending from the SVZ to the peri-infarct cortex, leading to an ultimate increase in the number of newly generated cortical neurons at $14-28$ days. While not specifically examining the migration of new neuroblasts, others similarly showed that VEGF overexpression enhanced striatal neurogenesis in adult rat brain after MCAO [138, 139], while infusion of VEGF into the lateral ventricle increased neurogenesis in the pericontusional cortex after focal TBI [31].

\section{Granulocyte Colony-Stimulating Factor}

The hematopoietic growth factor G-CSF has a welldefined role in stimulating the proliferation and differentiation of hematopoietic progenitor cells into neutrophils and modulating neutrophil actions and distribution in the body [140]. More recently, neuroprotective properties of endogenous and applied G-CSF have been established, and growing evidence suggests that G-CSF may also drive neurogenesis, with a role in survival, differentiation and migration of neural progenitor cells [141]. G-CSF and its receptor are widely expressed by neurons throughout the adult rat and human brain, and also by cells within the neurogenic regions of the SVZ and hippocampus $[142,143]$. Consistently, G-CSF receptor was also found expressed in cultured adult human and rat SVZ and hippocampal NPCs [142, 143], supporting a role for this ligand/receptor system in adult neurogenesis. When G-CSF was administered by peripheral infusion in rats subjected to MCAO, the recruitment of neuroblasts into the ischemic area of the neocortex was significantly enhanced, and the number of newly generated neurons in the dentate gyrus was also increased [143]. Similarly, G-CSF treatment increased the number of neuroblasts in the SVZ ipsilateral to the site of focal TBI [144]. G-CSF also promoted neuronal differentiation of adult NPCs isolated from rat SVZ and hippocampus [143]. Interestingly, G-CSF expression is dramatically upregulated in damaged tissue by approximately 100 fold after both experimental stroke [143] and TBI [145], suggesting that endogenous G-CSF may be critical for injury-induced neuronal differentiation of newly divided NPCs, as well as the recruitment of neuroblasts to the injury site.
Brain-Derived Neurotrophic Factor

$\mathrm{BDNF}$ is a prominent neurotrophin with an important role in regulating constitutive adult neurogenesis in both the hippocampus and SVZ. BDNF exists in two forms (pro-BDNF and mature BDNF) and mediates its diverse actions through two structurally distinct receptors: the p75 neurotrophin receptor (NTR), a member of the TNF receptor superfamily that binds all neurotrophins with a preference for pro- rather than mature BDNF, and its specific high-affinity receptor TrkB, a member of the Trk family of receptor tyrosine kinases [146]. To date, the ability of pro-BDNF to regulate adult neurogenesis is relatively unknown, with most studies assessing effects of the mature form.

Evidence exists for a role of BDNF in regulating neuronal commitment of NPCs of both the hippocampus and the SVZ. For example, cell culture studies have shown that BDNF is essential for the differentiation of hippocampal progenitors into neurons [147]. This effect may be mediated by p75NTR, which is expressed in cells of the dentate gyrus [148] and was shown to regulate neuronal commitment and survival of hippocampal precursors [149]. Consistently, mice lacking BDNF have reduced hippocampal neurogenesis due to hindered granule cell differentiation [150]. In the adult SVZ, a population of highly proliferative precursors expresses p75NTR and responds similarly to BDNF by committing to a neuronal fate [151]. Interestingly, p75NTR expression is decreased while TrkB expression is increased on immature dentate gyrus neuroblasts, with TrkB levels continue to increase as the cells reach maturity $[152,153]$. Studies using mice with TrkB deletion specifically from adult precursors demonstrated that TrkB is necessary for terminal differentiation and integration of new neurons into hippocampal circuits [154].

Besides neuronal differentiation, BDNF is also important for regulating SVZ NPC migration through the RMS to the olfactory bulb [for a recent review, see 155]. In mice genetically altered to lack the regulated secretion of BDNF, neuroblast migration was reduced and fewer new olfactory bulb neurons were evident, with no effect on NPC proliferation in the SVZ [156]. Consistently, infusion of BDNF into the lateral ventricles or viral overexpression in the anterior SVZ resulted in enhanced neuronal migration to the olfactory bulb and also into the adjacent striatum, while increasing the survival of new neurons [53, 157-160]. Interestingly, in vitro assays revealed that BDNF can both enhance motility of NPCs as well as act as a chemoattractant [161]. TrkB likely mediates the effects of BDNF on neuroblast migration, since it 
is specifically localized to migrating neuroblasts within the SVZ, RMS and subependymal layer of the olfactory bulb $[156,161,162]$. This is consistent with studies using explant culture assays showing that BDNF induced the migration of neuroblasts derived from early postnatal tissue, and that this effect was lost when TrkB was inhibited [161]. At present, there are disagreements in the literature in regard to whether p75NTR is also expressed by migratory neuroblasts in the RMS [155], and therefore ongoing work is necessary to clarify its potential contribution to BDNF-mediated neuroblast migration.

It can be hypothesized that endogenous BDNF is involved in injury-induced neurogenesis. Many studies of experimental stroke and TBI have shown that BDNF mRNA and protein expression is increased from hours to weeks after injury in the damaged tissue, as well as in remote regions including the hippocampus [163-168]. However, only a few studies have investigated the role of BDNF on neurogenesis following brain insults. In a quinolinic acid lesion model, BDNF overexpression enhanced the recruitment of NPCs to the lesioned striatum and promoted their neuronal differentiation and survival [159]. Similarly, in ischemia, intravenous BDNF stimulated NPC migration to the striatum, which coincided with improved neurological recovery [169].

\section{Basic Fibroblast Growth Factor}

FGF2 is a member of the FGF family displaying trophic effects in the brain during development [170] and having a major role in CNS injury responses [171]. FGF2 is widely distributed throughout the brain and is expressed by astrocytes, endothelium and some neuronal populations [172]. FGF2 signals predominantly through tyrosine kinase FGF receptor 1 (FGFR1), via complex intracrine and autocrine modes of action [173]. FGF2 is an essential mitogen for NPCs in vitro [174-177], while in vivo, the administration of FGF2 results in an increase in proliferation and neuronal differentiation in the SVZ, olfactory bulb and dentate gyrus [178-180].

FGF2 and FGFR1 are upregulated in several forms of adult brain injury, including trauma [181-183] and ischemia $[184,185]$, and both have been localized predominantly to reactive astrocytes around the lesioned tissue $[182,183]$. Evidence suggests that FGF2 and FGFR1 are both required for neurogenesis after cortical damage $[186,187]$, and a number of studies have shown that treatment with FGF2 enhances neurogenesis after brain injury by stimulating NPC proliferation and neuronal differentiation [188-191]. Relatively few studies have investigated the potential of FGF2 for mediating the migration of NPCs in pathological brain. In a chemotaxis assay using NPCs from neonatal rat SVZ, VEGF induced directional migration of NPCs via VEGFR2 signaling, and interestingly, this chemotactic response was dependent upon the presence of FGF2, which increased VEGFR2 expression [128]. Similarly, cultured adult NPCs transplanted into the olfactory bulbs of postnatal mice were able to undergo significant migration from the site of injection and subsequent neuronal maturation, only when the NPCs were exposed to FGF2 prior to grafting [192]. Finally, when NPCs overexpressing FGF2 were transplanted into neonatal ischemic cortex, they had increased proliferative activity and showed dramatically enhanced migration into the site of brain injury compared to nonoverexpressing NPC controls [193]. This effect was apparently mediated via an autocrine signaling loop, since FGF2-overexpressing NPCs did not affect the migratory behavior of coimplanted nonoverexpressing NPCs. Altogether, these data suggest that FGF2 may be important for enabling NPCs to respond to chemoattractant cues secreted at the site of injury.

\section{Epidermal Growth Factor}

EGF is important for the regulation of proliferation, differentiation, migration and survival of multiple cell types throughout the body. In the adult CNS, EGF receptor (EGFR) is highly expressed on stem cells and transitamplifying progenitor cells in the SVZ, and is also present at low levels on a subpopulation of SVZ neuroblasts [194-196]. It is well established that EGF and EGFR signaling regulates the proliferation of adult NPCs in the SVZ. For example, infusion of EGF into the lateral ventricle increased proliferation of adult SVZ NPCs in vivo $[51,179]$, and EGF is also necessary for the in vitro formation of neurospheres [174, 197]. Accordingly, in mice null for the EGFR agonist transforming growth factor (TGF) $\alpha$, a dramatic reduction of NPC proliferation was shown in the SVZ [198]. EGF may also stimulate migration of NPCs, since infusion of EGF into the lateral ventricle caused not only a striking increase in NPC proliferation, but also in their migration away from the lateral ventricle walls into adjacent normal brain parenchyma [51, 195, 199]. In support of a role in migration, application of EGF to neurospheres derived from adult mouse SVZ NPCs resulted in a rapid reorganization of the cytoskeleton and significant changes in cell structure typical of a migratory phenotype, which was accompanied by enhanced cell migration [200]. Furthermore, overexpression of EGFR confers migratory properties on SVZ precursors in vitro and in vivo [201]. However, Kim et al. [196] found 
that EGFR was only expressed at low levels on a small subpopulation of SVZ neuroblasts in adult mouse slice preparations, and exposure to TGF $\alpha$ significantly decreased the percentage of migrating cells. Altogether, these data demonstrate that further work is required to distinguish the role of EGF between the proliferation and migration of SVZ precursors.

Experimental evidence does suggest that EGF could potentially stimulate the migration of NPCs from the SVZ to adjacent brain regions in pathological contexts. EGF was increased in the injured region of the cortex to which SVZ cells migrated after cortical aspiration [202], while cerebral ischemia produced a larger number of EGFR-positive NPCs in the SVZ [20, 203]. Following nigrostriatal denervation, TGF $\alpha$ infusion into the striatum induced emigration of SVZ cells [204, 205], while reduction of EGFR signaling in progenitors expressing neuron glial antigen 2 decreased their proliferative and migratory response to demyelination [206]. Interestingly, Ninomiya et al. [203] showed that in the ischemic brain there was an increase in the number of NPCs but a decrease in neuroblasts during EGF infusion into the parenchyma; however, 6 days after the discontinuation of EGF delivery, there was a substantial rise in the number of neuroblasts in the SVZ and striatum. In a separate study, EGF infusion similarly increased the number of NPCs, which subsequently led to enhanced migration of neuroblasts into the ischemic striatum and the ultimate production of new striatal interneurons [20]. In the same study, migrating neuroblasts were associated with a network of cells positive for glial fibrillary acidic protein with elongated processes linking the SVZ to the striatal lesion, which was only present in the EGF-treated brains [20]. Similarly, in a rat explant culture model of cerebellar development, granule cell migration was enhanced following EGF exposure in association with elongation of glial processes [207]. Altogether, these results suggest that enhanced migration of SVZ cells into the striatum occurring after EGF infusion is likely indirect, resulting from an expanded progenitor cell population and amplified glial support.

\section{Concluding Remarks}

Activated microglia and reactive astrocytes play a major role in the neuroinflammatory response to ischemic injuries and TBI, releasing a plethora of pro- and antiinflammatory cytokines, chemokines and growth factors. While the role of such factors in mediating the in- flammatory response and contributing to neuronal degeneration has been well established, more recently it has been recognized that in the injured brain these same factors also support regenerative processes, including neurogenesis. Specifically, enhanced motility of NPCs and directional cues imparted by chemokines and growth factors are necessary to recruit new neuroblasts from the SVZ/RMS towards the damaged tissue. While a number of factors involved in stimulating injury-induced migration have been identified, their distinct ability in modulating motility or direction remains unclear in most, but not all, instances. For example, FGF2 has been shown to enable NPCs to respond to chemoattractants, while VEGF and CXCL12 appear to predominantly provide directional signals. Interestingly, BDNF and CCL2 can affect both motility and direction of migration, and this may depend upon whether they are being released in the SVZ or at the site of tissue damage. However, more studies are necessary to identify the relative importance of individual factors and determine which are most effective in supporting NPC migration, whether alone or in combination. It is also important to consider the balance between stimulating neuroblast recruitment and inhibiting other neurogenic stages, such as neuronal differentiation and survival of new cells, since chemokines and growth factors are known to have multiple inhibitory actions on the different stages of neurogenesis. Altogether, such insights could ultimately enable the development of new therapeutic approaches for the treatment of brain injury.

\section{Acknowledgements}

This research was supported by research grants and fellowships to N.B. and C.M.K. by the Victorian Neurotrauma Initiative and Transport Accident Commission, and by a National Health and Medical Research Council Fellowship to A.M.T.

References rogenesis: from precursors to network and physiology. Physiol Rev 2005;85:523-569.

-2 Doetsch F, Alvarez-Buylla A: Network of tangential pathways for neuronal migration in adult mammalian brain. Proc Natl Acad Sci USA 1996;93:14895-14900.

- 3 Hastings NB, Gould E: Rapid extension of axons into the CA3 region by adult-generated granule cells. J Comp Neurol 1999;413: 146-154 (erratum published in J Comp Neurol 1999;415:144). 
4 Lois C, Alvarez-Buylla A: Proliferating subventricular zone cells in the adult mammalian forebrain can differentiate into neurons and glia. Proc Natl Acad Sci USA 1993;90: 2074-2077.

5 Kernie SG, Parent JM: Forebrain neurogenesis after focal ischemic and traumatic brain injury. Neurobiol Dis 2010;37:267-274.

6 Ohira K: Injury-induced neurogenesis in the mammalian forebrain. Cell Mol Life Sci 2011;68:1645-1656.

7 Richardson RM, Sun D, Bullock MR: Neurogenesis after traumatic brain injury. Neurosurg Clin North Am 2007;18:169-181.

$\checkmark 8$ Winner B, Kohl Z, Gage FH: Neurodegenerative disease and adult neurogenesis. Eur J Neurosci 2011;33:1139-1151.

-9 Arvidsson A, Collin T, Kirik D, Kokaia Z, Lindvall O: Neuronal replacement from endogenous precursors in the adult brain after stroke. Nat Med 2002;8:963-970.

- 10 Jiang W, Gu W, Brannstrom T, Rosqvist R, Wester P: Cortical neurogenesis in adult rats after transient middle cerebral artery occlusion. Stroke 2001;32:1201-1207.

11 Magavi SS, Leavitt BR, Macklis JD: Induction of neurogenesis in the neocortex of adult mice. Nature 2000;405:951-955.

-12 Parent JM, Vexler ZS, Gong C, Derugin N, Ferriero DM: Rat forebrain neurogenesis and striatal neuron replacement after focal stroke. Ann Neurol 2002;52:802-813.

13 Cayre M, Canoll P, Goldman JE: Cell migration in the normal and pathological postnatal mammalian brain. Prog Neurobiol 2009; 88:41-63.

14 Leong SY, Turnley AM: Regulation of adult neural precursor cell migration. Neurochem Int 2011;59:382-393.

15 Ohab JJ, Carmichael ST: Poststroke neurogenesis: emerging principles of migration and localization of immature neurons. Neuroscientist 2008;14:369-380.

- 16 Thored P, Arvidsson A, Cacci E, Ahlenius H, Kallur T, Darsalia V, Ekdahl CT, Kokaia Z, Lindvall O: Persistent production of neurons from adult brain stem cells during recovery after stroke. Stem Cells 2006;24:739-747.

17 Jin K, Sun Y, Xie L, Peel A, Mao XO, Batteur $S$, Greenberg DA: Directed migration of neuronal precursors into the ischemic cerebral cortex and striatum. Mol Cell Neurosci 2003;24:171-189.

$\checkmark 18$ Ohab JJ, Fleming S, Blesch A, Carmichael ST: A neurovascular niche for neurogenesis after stroke. J Neurosci 2006;26:13007-13016.

19 Yamashita T, Ninomiya M, Hernandez Acosta P, Garcia-Verdugo JM, Sunabori T, Sakaguchi M, Adachi K, Kojima T, Hirota Y, Kawase T, Araki N, Abe K, Okano H, Sawamoto K: Subventricular zone-derived neuroblasts migrate and differentiate into mature neurons in the post-stroke adult striatum. J Neurosci 2006;26:6627-6636.
20 Teramoto T, Qiu J, Plumier J-C, Moskowitz MA: EGF amplifies the replacement of parvalbumin-expressing striatal interneurons after ischemia. J Clin Invest 2003;111:11251132.

21 Morganti-Kossmann MC, Yan E, Bye N: Animal models of traumatic brain injury: is there an optimal model to reproduce human brain injury in the laboratory? Injury 2010; 41(suppl 1):S10-S13.

22 Dash PK, Mach SA, Moore AN: Enhanced neurogenesis in the rodent hippocampus following traumatic brain injury. J Neurosci Res 2001;63:313-319.

23 Kernie SG, Erwin TM, Parada LF: Brain remodeling due to neuronal and astrocytic proliferation after controlled cortical injury in mice. J Neurosci Res 2001;66:317-326.

24 Ramaswamy S, Goings GE, Soderstrom KE, Szele FG, Kozlowski DA: Cellular proliferation and migration following a controlled cortical impact in the mouse. Brain Res 2005;1053:38-53.

25 Rola R, Mizumatsu S, Otsuka S, Morhardt DR, Noble-Haeusslein LJ, Fishman K, Potts MB, Fike JR: Alterations in hippocampal neurogenesis following traumatic brain injury in mice. Exp Neurol 2006;202:189199.

26 Salman H, Ghosh P, Kernie SG: Subventricular zone neural stem cells remodel the brain following traumatic injury in adult mice. J Neurotrauma 2004;21:283-292.

27 Chirumamilla S, Sun D, Bullock MR, Colello RJ: Traumatic brain injury induced cell proliferation in the adult mammalian central nervous system. J Neurotrauma 2002;19: 693-703.

-28 Sun D, Colello RJ, Daugherty WP, Kwon TH, McGinn MJ, Harvey HB, Bullock MR: Cell proliferation and neuronal differentiation in the dentate gyrus in juvenile and adult rats following traumatic brain injury. $\mathrm{J}$ Neurotrauma 2005;22:95-105.

29 Urrea C, Castellanos DA, Sagen J, Tsoulfas P, Bramlett HM, Dietrich WD: Widespread cellular proliferation and focal neurogenesis after traumatic brain injury in the rat. Restor Neurol Neurosci 2007;25:65-76.

30 Chen X-H, Iwata A, Nonaka M, Browne KD, Smith DH: Neurogenesis and glial proliferation persist for at least one year in the subventricular zone following brain trauma in rats. J Neurotrauma 2003;20:623-631.

31 Thau-Zuchman O, Shohami E, Alexandrovich AG, Leker RR: Vascular endothelial growth factor increases neurogenesis after traumatic brain injury. J Cereb Blood Flow Metab 2010;30:1008-1016.

32 Goings GE, Sahni V, Szele FG: Migration patterns of subventricular zone cells in adult mice change after cerebral cortex injury. Brain Res 2004;996:213-226.

- 33 Itoh T, Satou T, Nishida S, Hashimoto S, Ito $\mathrm{H}$ : Immature and mature neurons coexist among glial scars after rat traumatic brain injury. Neurol Res 2007;29:734-742.
34 Petraglia AL, Marky AH, Walker C, Thiyagarajan $\mathrm{M}$, Zlokovic BV: Activated protein $\mathrm{C}$ is neuroprotective and mediates new blood vessel formation and neurogenesis after controlled cortical impact. Neurosurgery 2010; 66:165-171, discussion 171-162.

35 Iadecola C, Anrather J: The immunology of stroke: from mechanisms to translation. Nat Med 2011;17:796-808.

-36 Leker RR, Shohami E, Leker RR, Shohami E: Cerebral ischemia and trauma - different etiologies yet similar mechanisms: neuroprotective opportunities. Brain Res Brain Res Rev 2002;39:55-73.

-37 Ziebell JM, Morganti-Kossmann MC: Involvement of pro- and anti-inflammatory cytokines and chemokines in the pathophysiology of traumatic brain injury. Neurotherapeutics 2010;7:22-30.

38 Das S, Basu A: Inflammation: a new candidate in modulating adult neurogenesis. J Neurosci Res 2008;86:1199-1208.

-39 Ekdahl CT, Kokaia Z, Lindvall O: Brain inflammation and adult neurogenesis: the dual role of microglia. Neuroscience 2009;158: 1021-1029.

40 Whitney NP, Eidem TM, Peng H, Huang Y, Zheng JC: Inflammation mediates varying effects in neurogenesis: relevance to the pathogenesis of brain injury and neurodegenerative disorders. J Neurochem 2009;108: 1343-1359.

-41 Rock RB, Gekker G, Hu S, Sheng WS, Cheeran M, Lokensgard JR, Peterson PK: Role of microglia in central nervous system infections. Clin Microbiol Rev 2004;17:942-964.

42 Ekdahl CT, Claasen J-H, Bonde S, Kokaia Z, Lindvall O: Inflammation is detrimental for neurogenesis in adult brain. Proc Natl Acad Sci USA 2003;100:13632-13637.

43 Hoehn BD, Palmer TD, Steinberg GK: Neurogenesis in rats after focal cerebral ischemia is enhanced by indomethacin. Stroke 2005; 36:2718-2724.

44 Liu Z, Fan Y, Won SJ, Neumann M, Hu D, Zhou L, Weinstein PR, Liu J: Chronic treatment with minocycline preserves adult new neurons and reduces functional impairment after focal cerebral ischemia. Stroke 2007;38: 146-152.

45 Monje ML, Mizumatsu S, Fike JR, Palmer TD: Irradiation induces neural precursorcell dysfunction. Nat Med 2002;8:955-962.

- 46 Iosif RE, Ekdahl CT, Ahlenius H, Pronk CJH, Bonde S, Kokaia Z, Jacobsen S-EW, Lindvall O: Tumor necrosis factor receptor 1 is a negative regulator of progenitor proliferation in adult hippocampal neurogenesis. J Neurosci 2006;26:9703-9712.

47 Liu Y-P, Lin H-I, Tzeng S-F: Tumor necrosis factor-alpha and interleukin-18 modulate neuronal cell fate in embryonic neural progenitor culture. Brain Res 2005; 1054:152158.

48 Monje ML, Toda H, Palmer TD: Inflammatory blockade restores adult hippocampal neurogenesis. Science 2003;302:1760-1765. 
-49 Vallieres L, Campbell IL, Gage FH, Sawchenko PE: Reduced hippocampal neurogenesis in adult transgenic mice with chronic astrocytic production of interleukin-6. J Neurosci 2002;22:486-492.

-50 Butovsky O, Ziv Y, Schwartz A, Landa G, Talpalar AE, Pluchino S, Martino G, Schwartz M: Microglia activated by IL-4 or IFN-gamma differentially induce neurogenesis and oligodendrogenesis from adult stem/progenitor cells. Mol Cell Neurosci 2006;31: 149-160.

-51 Craig CG, Tropepe V, Morshead CM, Reynolds BA, Weiss S, van der Kooy D: In vivo growth factor expansion of endogenous subependymal neural precursor cell populations in the adult mouse brain. J Neurosci 1996;16:2649-2658.

- 52 Imitola J, Raddassi K, Park KI, Mueller FJ, Nieto M, Teng YD, Frenkel D, Li J, Sidman RL, Walsh CA, Snyder EY, Khoury SJ: Directed migration of neural stem cells to sites of CNS injury by the stromal cell-derived factor 1alpha/CXC chemokine receptor 4 pathway. Proc Natl Acad Sci USA 2004;101: 18117-18122.

-53 Pencea V, Bingaman KD, Wiegand SJ, Luskin MB: Infusion of brain-derived neurotrophic factor into the lateral ventricle of the adult rat leads to new neurons in the parenchyma of the striatum, septum, thalamus, and hypothalamus. J Neurosci 2001;21:6706-6717.

-54 Yan Y-P, Sailor KA, Lang BT, Park S-W, Vemuganti R, Dempsey RJ: Monocyte chemoattractant protein-1 plays a critical role in neuroblast migration after focal cerebral ischemia. J Cereb Blood Flow Metab 2007;27: 1213-1224.

-55 Chen Y, Swanson RA: Astrocytes and brain injury. J Cereb Blood Flow Metab 2003;23: 137-149.

-56 Ridet JL, Malhotra SK, Privat A, Gage FH: Reactive astrocytes: cellular and molecular cues to biological function. Trends Neurosci 1997;20:570-577 (erratum published in Trends Neurosci 1998;21:80).

57 Song H, Stevens CF, Gage FH: Astroglia induce neurogenesis from adult neural stem cells. Nature 2002;417:39-44.

- 58 Bajetto A, Bonavia R, Barbero S, Schettini G: Characterization of chemokines and their receptors in the central nervous system: physiopathological implications. J Neurochem 2002;82:1311-1329.

59 Semple BD, Kossmann T, Morganti-Kossmann MC: Role of chemokines in CNS health and pathology: a focus on the CCL2/ CCR2 and CXCL8/CXCR2 networks. J Cereb Blood Flow Metab 2010;30:459-473.

-60 Cartier L, Hartley O, Dubois-Dauphin M, Krause KH: Chemokine receptors in the central nervous system: role in brain inflammation and neurodegenerative diseases. Brain Res Brain Res Rev 2005;48:16-42.
61 Tran PB, Ren D, Veldhouse TJ, Miller RJ: Chemokine receptors are expressed widely by embryonic and adult neural progenitor cells. J Neurosci Res 2004;76:20-34.

62 Turbic A, Leong SY, Turnley AM: Chemokines and inflammatory mediators interact to regulate adult murine neural precursor cell proliferation, survival and differentiation. PLoS One 2011;6:e25406.

63 Krathwohl MD, Kaiser JL: Chemokines promote quiescence and survival of human neural progenitor cells. Stem Cells 2004;22:109118.

64 Ni HT, Hu S, Sheng WS, Olson JM, Cheeran MC, Chan AS, Lokensgard JR, Peterson PK: High-level expression of functional chemokine receptor CXCR4 on human neural precursor cells. Brain Res Dev Brain Res 2004; 152:159-169.

65 Berman JW, Guida MP, Warren J, Amat J, Brosnan CF: Localization of monocyte chemoattractant peptide-1 expression in the central nervous system in experimental autoimmune encephalomyelitis and trauma in the rat. J Immunol 1996;156:3017-3023.

66 Conductier G, Blondeau N, Guyon A, Nahon JL, Rovere C: The role of monocyte chemoattractant protein MCP1/CCL2 in neuroinflammatory diseases. J Neuroimmunol 2010; 224:93-100.

67 Gordon RJ, McGregor AL, Connor B: Chemokines direct neural progenitor cell migration following striatal cell loss. Mol Cell Neurosci 2009;41:219-232.

68 Knerlich-Lukoschus F, von der RoppBrenner B, Lucius R, Mehdorn HM, HeldFeindt J: Chemokine expression in the white matter spinal cord precursor niche after force-defined spinal cord contusion injuries in adult rats. Glia 2010;58:916-931.

69 McTigue DM, Tani M, Krivacic K, Chernosky A, Kelner GS, Maciejewski D, Maki R, Ransohoff RM, Stokes BT: Selective chemokine mRNA accumulation in the rat spinal cord after contusion injury. J Neurosci Res 1998;53:368-376.

70 Lalor SJ, Segal BM: Lymphoid chemokines in the CNS. J Neuroimmunol 2010;224:56-61.

71 Bhattacharyya BJ, Banisadr G, Jung H, Ren D, Cronshaw DG, Zou Y, Miller RJ: The chemokine stromal cell-derived factor-1 regulates GABAergic inputs to neural progenitors in the postnatal dentate gyrus. J Neurosci 2008;28:6720-6730.

72 Dziembowska M, Tham TN, Lau P, Vitry S, Lazarini F, Dubois-Dalcq M: A role for CXCR4 signaling in survival and migration of neural and oligodendrocyte precursors. Glia 2005;50:258-269.

73 Kasemeier-Kulesa JC, McLennan R, Romine MH, Kulesa PM, Lefcort F: CXCR4 controls ventral migration of sympathetic precursor cells. J Neurosci 2010;30:13078-13088.
4 Lazarini F, Tham TN, Casanova P, Arenzana-Seisdedos F, Dubois-Dalcq M: Role of the alpha-chemokine stromal cell-derived factor (SDF-1) in the developing and mature central nervous system. Glia 2003;42:139-148.

75 Reiss K, Mentlein R, Sievers J, Hartmann D: Stromal cell-derived factor 1 is secreted by meningeal cells and acts as chemotactic factor on neuronal stem cells of the cerebellar external granular layer. Neuroscience 2002; 115:295-305.

76 Tiveron MC, Rossel M, Moepps B, Zhang YL, Seidenfaden R, Favor J, Konig N, Cremer $\mathrm{H}$ : Molecular interaction between projection neuron precursors and invading interneurons via stromal-derived factor 1 (CXCL12)/ CXCR4 signaling in the cortical subventricular zone/intermediate zone. J Neurosci 2006;26:13273-13278.

77 Li M, Chang CJ, Lathia JD, Wang L, Pacenta HL, Cotleur A, Ransohoff RM: Chemokine receptor CXCR4 signaling modulates the growth factor-induced cell cycle of self-renewing and multipotent neural progenitor cells. Glia 2011;59:108-118.

78 Hagihara K, Zhang EE, Ke YH, Liu G, Liu JJ, Rao Y, Feng GS: SHP2 acts downstream of SDF-1alpha/CXCR4 in guiding granule cell migration during cerebellar development. Dev Biol 2009;334:276-284

79 Yu T, Huang H, Li HF: Stromal cell-derived factor-1 promotes migration of cells from the upper rhombic lip in cerebellar development. J Neurosci Res 2010;88:2775-2786.

80 Olesnicky Killian EC, Birkholz DA, Artinger $\mathrm{KB}$ : A role for chemokine signaling in neural crest cell migration and craniofacial development. Dev Biol 2009;333:161-172.

81 Diotel N, Vaillant C, Gueguen MM, Mironov S, Anglade I, Servili A, Pellegrini E, Kah O CXCR4 and CXCL12 expression in radial glial cells of the brain of adult zebrafish. J Comp Neurol 2010;518:4855-4876.

82 Liu XS, Chopp M, Santra M, Hozeska-Solgot A, Zhang RL, Wang L, Teng H, Lu M, Zhang ZG: Functional response to SDF1 alpha through over-expression of CXCR4 on adult subventricular zone progenitor cells. Brain Res 2008;1226:18-26.

83 Peng H, Huang Y, Rose J, Erichsen D, Herek S, Fujii N, Tamamura H, Zheng J: Stromal cell-derived factor 1-mediated CXCR4 signaling in rat and human cortical neural progenitor cells. J Neurosci Res 2004;76:35-50.

- 84 Widera D, Holtkamp W, Entschladen F, Niggemann B, Zanker K, Kaltschmidt B, Kaltschmidt C: MCP-1 induces migration of adult neural stem cells. Eur J Cell Biol 2004; 83:381-387.

85 Li S, Deng L, Gong L, Bian H, Dai Y, Wang Y: Upregulation of CXCR4 favoring neural-like cells migration via AKT activation. Neurosci Res 2010;67:293-299. 
86 Kokovay E, Goderie S, Wang Y, Lotz S, Lin G, Sun Y, Roysam B, Shen Q, Temple S: Adult SVZ lineage cells home to and leave the vascular niche via differential responses to SDF1/CXCR4 signaling. Cell Stem Cell 2010; 7:163-173.

-87 Tiveron M-C, Boutin C, Daou P, Moepps B, Cremer $\mathrm{H}$ : Expression and function of CXCR7 in the mouse forebrain. J Neuroimmunol 2010;224:72-79.

- 88 Ceradini DJ, Kulkarni AR, Callaghan MJ, Tepper OM, Bastidas N, Kleinman ME, Capla JM, Galiano RD, Levine JP, Gurtner GC: Progenitor cell trafficking is regulated by hypoxic gradients through HIF-1 induction of SDF-1. Nat Med 2004;10:858-864.

89 Hill WD, Hess DC, Martin-Studdard A, Carothers JJ, Zheng J, Hale D, Maeda M, Fagan SC, Carroll JE, Conway SJ: SDF-1 (CXCL12) is upregulated in the ischemic penumbra following stroke: association with bone marrow cell homing to injury. J Neuropathol Exp Neurol 2004;63:84-96.

-90 Stumm RK, Rummel J, Junker V, Culmsee C, Pfeiffer M, Krieglstein J, Hollt V, Schulz S: A dual role for the SDF-1/CXCR4 chemokine receptor system in adult brain: isoform-selective regulation of SDF-1 expression modulates CXCR4-dependent neuronal plasticity and cerebral leukocyte recruitment after focal ischemia. J Neurosci 2002;22:5865-5878.

-91 Itoh T, Satou T, Ishida H, Nishida S, Tsubaki $\mathrm{M}$, Hashimoto S, Ito $\mathrm{H}$ : The relationship between SDF-1alpha/CXCR4 and neural stem cells appearing in damaged area after traumatic brain injury in rats. Neurol Res 2009; 31:90-102.

\$2 Liu XS, Zhang ZG, Zhang RL, Gregg SR, Wang L, Yier T, Chopp M: Chemokine ligand 2 (CCL2) induces migration and differentiation of subventricular zone cells after stroke. J Neurosci Res 2007;85:2120-2125.

93 Robin AM, Zhang ZG, Wang L, Zhang RL, Katakowski M, Zhang L, Wang Y, Zhang C, Chopp M: Stromal cell-derived factor 1alpha mediates neural progenitor cell motility after focal cerebral ischemia. J Cereb Blood Flow Metab 2006;26:125-134.

94 Che X, Ye W, Panga L, Wu DC, Yang GY: Monocyte chemoattractant protein-1 expressed in neurons and astrocytes during focal ischemia in mice. Brain Res 2001;902: 171-177.

\$95 Gourmala NG, Buttini M, Limonta S, Sauter A, Boddeke HW: Differential and time-dependent expression of monocyte chemoattractant protein-1 mRNA by astrocytes and macrophages in rat brain: effects of ischemia and peripheral lipopolysaccharide administration. J Neuroimmunol 1997;74:35-44.

96 Rancan M, Otto VI, Hans OHJ, Gerlach I, Jork R, Trentz O, Kossmann T, MorgantiKossmann MC: Upregulation of ICAM-1 and MCP-1 but not of MIP-2 and sensorimotor deficit in response to traumatic axonal injury in rats J Neurosci Res 2001;63:438446.
97 Rhodes JKJ, Sharkey J, Andrews PJD: The temporal expression, cellular localization, and inhibition of the chemokines MIP-2 and MCP-1 after traumatic brain injury in the rat. J Neurotrauma 2009;26:507-525.

-98 Semple BD, Bye N, Rancan M, Ziebell JM, Morganti-Kossmann MC: Role of CCL2 (MCP-1) in traumatic brain injury (TBI): evidence from severe TBI patients and $\mathrm{CCL}^{-/-}$mice. J Cereb Blood Flow Metab 2010;30:769-782.

99 Vrotsos EG, Sugaya K: MCP-1-induced migration of NT2 neuroprogenitor cells involving APP signaling. Cell Mol Neurobiol 2009;29:373-381.

100 Magge SN, Malik SZ, Royo NC, Chen HI, Yu L, Snyder EY, O’Rourke DM, Watson DJ: Role of monocyte chemoattractant protein-1 (MCP-1/CCL2) in migration of neural progenitor cells toward glial tumors. J Neurosci Res 2009;87:1547-1555.

101 Belmadani A, Tran PB, Ren D, Miller RJ: Chemokines regulate the migration of neural progenitors to sites of neuroinflammation. J Neurosci 2006;26:3182-3191.

102 Hattermann K, Ludwig A, Gieselmann V, Held-Feindt J, Mentlein R: The chemokine CXCL16 induces migration and invasion of glial precursor cells via its receptor CXCR6. Mol Cell Neurosci 2008;39:133-141.

103 Weiss N, Deboux C, Chaverot N, Miller F, Baron-Van Evercooren A, Couraud PO, Cazaubon S: IL8 and CXCL13 are potent chemokines for the recruitment of human neural precursor cells across brain endothelial cells. J Neuroimmunol 2010;223:131-134.

104 Gordon RJ, et al: Chemokines influence the migration and fate of neural precursor cells from the young adult and middle-aged rat subventricular zone. Exp Neurol 2012;233: 587-594.

105 Theveneau E, Marchant L, Kuriyama S, Gull M, Moepps B, Parsons M, Mayor R: Collective chemotaxis requires contact-dependent cell polarity. Dev Cell 2010;19:3953.

106 Mocchetti I, Wrathall JR: Neurotrophic factors in central nervous system trauma. J Neurotrauma 1995;12:853-870.

107 Velly L, Pellegrini L, Guillet B, Bruder N, Pisano P: Erythropoietin 2nd cerebral protection after acute injuries: a double-edged sword? Pharmacol Ther 2010;128:445-459.

108 Buemi M, Cavallaro E, Floccari F, Sturiale A, Aloisi C, Trimarchi M, Grasso G, Corica F, Frisina N: Erythropoietin and the brain: from neurodevelopment to neuroprotection. Clin Sci 2002;103:275-282.

109 Shingo T, Sorokan ST, Shimazaki T, Weiss S: Erythropoietin regulates the in vitro and in vivo production of neuronal progenitors by mammalian forebrain neural stem cells. J Neurosci 2001;21:9733-9743.

110 Ransome MI, Turnley AM: Systemically delivered erythropoietin transiently enhances adult hippocampal neurogenesis. J Neurochem 2007;102:1953-1965.
11 Tsai PT, Ohab JJ, Kertesz N, Groszer M, Matter C, Gao J, Liu X, Wu H, Carmichael ST: A critical role of erythropoietin receptor in neurogenesis and post-stroke recovery. J Neurosci 2006;26:1269-1274.

112 Marti HH, Gassmann M, Wenger RH, Kvietikova I, Morganti-Kossmann MC, Kossmann T, Trentz O, Bauer C: Detection of erythropoietin in human liquor: intrinsic erythropoietin production in the brain. Kidney Int 1997;51:416-418.

113 Siren AL, Knerlich F, Poser W, Gleiter CH, Bruck W, Ehrenreich H: Erythropoietin and erythropoietin receptor in human ischemic/hypoxic brain. Acta Neuropathol (Berl) 2001;101:271-276.

114 Bernaudin M, Marti HH, Roussel S, Divoux D, Nouvelot A, MacKenzie ET, Petit E: A potential role for erythropoietin in focal permanent cerebral ischemia in mice. J Cereb Blood Flow Metab 1999;19:643-651.

115 Liao ZB, Zhi XG, Shi QH, He ZH: Recombinant human erythropoietin administration protects cortical neurons from traumatic brain injury in rats. Eur J Neurol 2008;15:140-149.

116 Iwai M, Cao G, Yin W, Stetler RA, Liu J, Chen J: Erythropoietin promotes neuronal replacement through revascularization and neurogenesis after neonatal hypoxia/ischemia in rats. Stroke 2007;38:2795-2803.

117 Kolb B, Morshead C, Gonzalez C, Kim M, Gregg C, Shingo T, Weiss S: Growth factorstimulated generation of new cortical tissue and functional recovery after stroke damage to the motor cortex of rats. J Cereb Blood Flow Metab 2007;27:983-997.

118 Wang L, Zhang Z, Wang Y, Zhang R, Chopp $\mathrm{M}$ : Treatment of stroke with erythropoietin enhances neurogenesis and angiogenesis and improves neurological function in rats. Stroke 2004;35:1732-1737.

119 Xiong Y, Mahmood A, Lu D, Qu C, Goussev A, Schallert T, Chopp M: Role of gender in outcome after traumatic brain injury and therapeutic effect of erythropoietin in mice. Brain Res 2007;1185:301-312.

120 Wang L, Zhang ZG, Zhang RL, Gregg SR, Hozeska-Solgot A, LeTourneau Y, Wang Y, Chopp M: Matrix metalloproteinase 2 (MMP2) and MMP9 secreted by erythropoietin-activated endothelial cells promote neural progenitor cell migration. J Neurosci 2006;26:5996-6003.

121 Dvorak HF, Brown LF, Detmar M, Dvorak AM: Vascular permeability factor/vascular endothelial growth factor, microvascular hyperpermeability, and angiogenesis. Am J Pathol 1995;146:1029-1039.

122 Matsumoto T, Claesson-Welsh L: VEGF receptor signal transduction. Sci STKE 2001; 2001:re21.

123 Robinson CJ, Stringer SE: The splice variants of vascular endothelial growth factor (VEGF) and their receptors. J Cell Sci 2001; 114:853-865. 
124 Rosenstein JM, Mani N, Khaibullina A, 135 Hayashi T, Abe K, Suzuki H, Itoyama Y: Krum JM: Neurotrophic effects of vascular endothelial growth factor on organotypic cortical explants and primary cortical neurons. J Neurosci 2003;23:11036-11044.

- 125 Svensson B, Peters M, Konig H-G, Poppe M, Levkau B, Rothermundt M, Arolt V, Kogel D, Prehn JHM: Vascular endothelial growth factor protects cultured rat hippocampal neurons against hypoxic injury via an antiexcitotoxic, caspase-independent mechanism. J Cereb Blood Flow Metab 2002;22:1170-1175.

126 Ogunshola OO, Antic A, Donoghue MJ, Fan S-Y, Kim H, Stewart WB, Madri JA, Ment LR: Paracrine and autocrine functions of neuronal vascular endothelial growth factor (VEGF) in the central nervous system. J Biol Chem 2002;277:11410-11415.

$\checkmark 127$ Sondell M, Sundler F, Kanje M: Vascular endothelial growth factor is a neurotrophic factor which stimulates axonal outgrowth through the FLK-1 receptor. Eur J Neurosci 2000;12:4243-4254.

- 128 Zhang H, Vutskits L, Pepper MS, Kiss JZ: VEGF is a chemoattractant for FGF-2-stimulated neural progenitors. J Cell Biol 2003; 163:1375-1384.

129 Fabel K, Fabel K, Tam B, Kaufer D, Baiker A, Simmons N, Kuo CJ, Palmer TD: VEGF is necessary for exercise-induced adult hippocampal neurogenesis. Eur J Neurosci 2003;18:2803-2812.

130 Jin K, Zhu Y, Sun Y, Mao XO, Xie L, Greenberg DA: Vascular endothelial growth factor (VEGF) stimulates neurogenesis in vitro and in vivo. Proc Natl Acad Sci USA 2002;99:11946-11950.

-131 Sun Y, Jin K, Childs JT, Xie L, Mao XO, Greenberg DA: Vascular endothelial growth factor-B (VEGFB) stimulates neurogenesis: evidence from knockout mice and growth factor administration. Dev Biol 2006;289:329-335.

132 Wittko IM, Schanzer A, Kuzmichev A, Schneider FT, Shibuya M, Raab S, Plate KH: VEGFR-1 regulates adult olfactory bulb neurogenesis and migration of neural progenitors in the rostral migratory stream in vivo. J Neurosci 2009;29:8704-8714.

133 Xu Q, Wang S, Jiang X, Zhao Y, Gao M, Zhang Y, Wang X, Tano K, Kanehara M, Zhang W, Ishida T: Hypoxia-induced astrocytes promote the migration of neural progenitor cells via vascular endothelial factor, stem cell factor, stromal-derived factor-1alpha and monocyte chemoattractant protein-1 upregulation in vitro. Clin Exp Pharmacol Physiol 2007;34:624-631.

134 Dore-Duffy P, Wang X, Mehedi A, Kreipke CW, Rafols JA: Differential expression of capillary VEGF isoforms following traumatic brain injury. Neurol Res 2007;29: 395-403. Rapid induction of vascular endothelial growth factor gene expression after transient middle cerebral artery occlusion in rats. Stroke 1997;28:2039-2044.

136 Skold MK, von Gertten C, SandbergNordqvist A-C, Mathiesen T, Holmin S: VEGF and VEGF receptor expression after experimental brain contusion in rat. J Neurotrauma 2005;22:353-367.

137 Wang Y, Jin K, Mao XO, Xie L, Banwait S, Marti HH, Greenberg DA: VEGF-overexpressing transgenic mice show enhanced post-ischemic neurogenesis and neuromigration. J Neurosci Res 2007;85:740-747.

138 Li S-F, Sun Y-B, Meng Q-H, Li S-R, Yao W-C, Hu G-J, Li Z-J, Wang R-Z: Recombinant adeno-associated virus serotype 1-vascular endothelial growth factor promotes neurogenesis and neuromigration in the subventricular zone and rescues neuronal function in ischemic rats. Neurosurgery 2009;65:771-779, discussion 779.

139 Wang Y-Q, Guo X, Qiu M-H, Feng X-Y, Sun F-Y: VEGF overexpression enhances striatal neurogenesis in brain of adult rat after a transient middle cerebral artery occlusion. J Neurosci Res 2007;85:73-82.

140 Demetri GD, Griffin JD: Granulocyte colony-stimulating factor and its receptor. Blood 1991;78:2791-2808.

141 Solaroglu I, Cahill J, Jadhav V, Zhang JH: A novel neuroprotectant granulocyte-colony stimulating factor. Stroke 2006;37:11231128.

142 Jung K-H, Chu K, Lee S-T, Kim S-J, Sinn D-I, Kim SU, Kim M, Roh J-K: Granulocyte colony-stimulating factor stimulates neurogenesis via vascular endothelial growth factor with STAT activation. Brain Res 2006;1073-1074:190-201.

143 Schneider A, Kruger C, Steigleder T, Weber D, Pitzer C, Laage R, Aronowski J, Maurer MH, Gassler N, Mier W, Hasselblatt M, Kollmar R, Schwab S, Sommer C, Bach A, Kuhn H-G, Schabitz W-R: The hematopoietic factor G-CSF is a neuronal ligand that counteracts programmed cell death and drives neurogenesis. J Clin Invest 2005; 115: 2083-2098.

144 Yang D-Y, Chen Y-J, Wang M-F, Pan H-C, Chen S-Y, Cheng F-C: Granulocyte colonystimulating factor enhances cellular proliferation and motor function recovery on rats subjected to traumatic brain injury. Neurol Res 2010;32:1041-1049.

145 Bye N, Habgood MD, Callaway JK, Malakooti N, Potter A, Kossmann T, MorgantiKossmann MC: Transient neuroprotection by minocycline following traumatic brain injury is associated with attenuated microglial activation but no changes in cell apoptosis or neutrophil infiltration. Exp Neurol 2007;204:220-233.
146 Chao MV: Neurotrophins and their receptors: a convergence point for many signalling pathways. Nat Rev Neurosci 2003;4: 299-309.

147 Bull ND, Bartlett PF: The adult mouse hippocampal progenitor is neurogenic but not a stem cell. J Neurosci 2005;25:1081510821.

148 Barrett GL, Greferath U, Barker PA, Trieu J, Bennie A: Co-expression of the p75 neurotrophin receptor and neurotrophin receptor-interacting melanoma antigen homolog in the mature rat brain. Neuroscience 2005; 133:381-392.

149 Catts VS, Al-Menhali N, Burne THJ, Colditz MJ, Coulson EJ: The p75 neurotrophin receptor regulates hippocampal neurogenesis and related behaviours. Eur J Neurosci 2008;28:883-892.

150 Chan JP, Cordeira J, Calderon GA, Iyer LK, Rios M: Depletion of central BDNF in mice impedes terminal differentiation of new granule neurons in the adult hippocampus. Mol Cell Neurosci 2008;39:372-383.

151 Young KM, Fogarty M, Kessaris N, Richardson WD: Subventricular zone stem cells are heterogeneous with respect to their embryonic origins and neurogenic fates in the adult olfactory bulb. J Neurosci 2007;27: 8286-8296.

152 Bibel M, Hoppe E, Barde YA: Biochemical and functional interactions between the neurotrophin receptors Trk and p75NTR. EMBO J 1999;18:616-622.

153 Donovan MH, Yamaguchi M, Eisch AJ: Dynamic expression of TrkB receptor protein on proliferating and maturing cells in the adult mouse dentate gyrus. Hippocampus 2008;18:435-439.

154 Bergami M, Rimondini R, Santi S, Blum R, Gotz M, Canossa M: Deletion of TrkB in adult progenitors alters newborn neuron integration into hippocampal circuits and increases anxiety-like behavior. Proc Natl Acad Sci USA 2008;105:15570-15575.

155 Bath KG, Lee FS: Neurotrophic factor control of adult SVZ neurogenesis. Dev Neurobiol 2010;70:339-349.

156 Bath KG, Mandairon N, Jing D, Rajagopal R, Kapoor R, Chen Z-Y, Khan T, Proenca CC, Kraemer R, Cleland TA, Hempstead BL, Chao MV, Lee FS: Variant brain-derived neurotrophic factor (Val66Met) alters adult olfactory bulb neurogenesis and spontaneous olfactory discrimination. J Neurosci 2008;28:2383-2393.

157 Benraiss A, Chmielnicki E, Lerner K, Roh D, Goldman SA: Adenoviral brain-derived neurotrophic factor induces both neostriatal and olfactory neuronal recruitment from endogenous progenitor cells in the adult forebrain. J Neurosci 2001;21:67186731 . 
158 Chmielnicki E, Benraiss A, Economides 169 Schabitz W-R, Steigleder T, Cooper-Kuhn AN, Goldman SA: Adenovirally expressed noggin and brain-derived neurotrophic factor cooperate to induce new medium spiny neurons from resident progenitor cells in the adult striatal ventricular zone. J Neurosci 2004;24:2133-2142.

159 Henry RA, Hughes SM, Connor B: AAVmediated delivery of BDNF augments neurogenesis in the normal and quinolinic acid-lesioned adult rat brain. Eur J Neurosci 2007;25:3513-3525.

160 Zigova T, Pencea V, Wiegand SJ, Luskin $\mathrm{MB}$ : Intraventricular administration of BDNF increases the number of newly generated neurons in the adult olfactory bulb. Mol Cell Neurosci 1998;11:234-245.

-161 Chiaramello S, Dalmasso G, Bezin L, Marcel D, Jourdan F, Peretto P, Fasolo A, De Marchis S: BDNF/TrkB interaction regulates migration of SVZ precursor cells via PI3-K and MAP-K signalling pathways. Eur J Neurosci 2007;26:1780-1790.

$\checkmark 162$ Bagley JA, Belluscio L: Dynamic imaging reveals that brain-derived neurotrophic factor can independently regulate motility and direction of neuroblasts within the rostral migratory stream. Neuroscience 2010; 169:1449-1461.

163 Chen J, Zhang C, Jiang H, Li Y, Zhang L, Robin A, Katakowski M, Lu M, Chopp M: Atorvastatin induction of VEGFf and BDNF promotes brain plasticity after stroke in mice. J Cereb Blood Flow Metab 2005;25:281-290.

- 164 Ferrer I, Krupinski J, Goutan E, Marti E, Ambrosio S, Arenas E: Brain-derived neurotrophic factor reduces cortical cell death by ischemia after middle cerebral artery occlusion in the rat. Acta Neuropathol (Berl) 2001;101:229-238.

165 Griesbach GS, Hovda DA, Molteni R, Gomez-Pinilla F: Alterations in BDNF and synapsin I within the occipital cortex and hippocampus after mild traumatic brain injury in the developing rat: reflections of injury-induced neuroplasticity. J Neurotrauma 2002;19:803-814.

-166 Hicks RR, Numan S, Dhillon HS, Prasad MR, Seroogy KB: Alterations in BDNF and NT-3 mRNAs in rat hippocampus after experimental brain trauma. Brain Res Mol Brain Res 1997;48:401-406.

167 Mahmood A, Goussev A, Kazmi H, Qu C, Lu D, Chopp M: Long-term benefits after treatment of traumatic brain injury with simvastatin in rats. Neurosurgery 2009;65: 187-191, discussion 191-192.

168 Oyesiku NM, Evans CO, Houston S, Darrell RS, Smith JS, Fulop ZL, Dixon CE, Stein DG: Regional changes in the expression of neurotrophic factors and their receptors following acute traumatic brain injury in the adult rat brain. Brain Res 1999;833:161172 . CM, Schwab S, Sommer C, Schneider A, Kuhn HG: Intravenous brain-derived neurotrophic factor enhances poststroke sensorimotor recovery and stimulates neurogenesis. Stroke 2007;38:2165-2172.

170 Abe K, Saito H: Effects of basic fibroblast growth factor on central nervous system functions. Pharmacol Res 2001;43:307-312.

171 Baird A: Fibroblast growth factors: activities and significance of non-neurotrophin neurotrophic growth factors. Curr Opin Neurobiol 1994;4:78-86.

172 Woodward WR, Nishi R, Meshul CK, Williams TE, Coulombe M, Eckenstein FP: Nuclear and cytoplasmic localization of basic fibroblast growth factor in astrocytes and CA2 hippocampal neurons. J Neurosci 1992;12:142-152.

173 Johnson DE, Williams LT: Structural and functional diversity in the FGF receptor multigene family. Adv Cancer Res 1993;60: $1-41$.

174 Gritti A, Frolichsthal-Schoeller P, Galli R, Parati EA, Cova L, Pagano SF, Bjornson CR, Vescovi AL: Epidermal and fibroblast growth factors behave as mitogenic regulators for a single multipotent stem cell-like population from the subventricular region of the adult mouse forebrain. J Neurosci 1999;19:3287-3297.

175 Kilpatrick TJ, Bartlett PF: Cloned multipotential precursors from the mouse cerebrum require FGF-2, whereas glial restricted precursors are stimulated with either FGF-2 or EGF. J Neurosci 1995;15:36533661.

176 Richards LJ, Kilpatrick TJ, Bartlett PF: De novo generation of neuronal cells from the adult mouse brain. Proc Natl Acad Sci USA 1992;89:8591-8595.

177 Tropepe V, Sibilia M, Ciruna BG, Rossant J, Wagner EF, van der Kooy D: Distinct neural stem cells proliferate in response to EGF and FGF in the developing mouse telencephalon. Dev Biol 1999;208:166-188.

178 Jin K, Sun Y, Xie L, Batteur S, Mao XO, Smelick C, Logvinova A, Greenberg DA: Neurogenesis and aging: FGF-2 and HBEGF restore neurogenesis in hippocampus and subventricular zone of aged mice. Ag-

$>179$ Kuhn HG, Winkler J, Kempermann G, Thal LJ, Gage FH: Epidermal growth factor and fibroblast growth factor-2 have different effects on neural progenitors in the adult rat brain. J Neurosci 1997;17:58205829.

180 Wagner JP, Black IB, DiCicco-Bloom E: Stimulation of neonatal and adult brain neurogenesis by subcutaneous injection of basic fibroblast growth factor. J Neurosci 1999; 19:6006-6016.

181 Frautschy SA, Walicke PA, Baird A: Localization of basic fibroblast growth factor and its mRNA after CNS injury. Brain Res 1991; 553:291-299. ing Cell 2003;2:175-183.
82 Gomez-Pinilla F, Vu L, Cotman CW: Regulation of astrocyte proliferation by FGF-2 and heparan sulfate in vivo. J Neurosci 1995;15:2021-2029.

183 Smith C, Berry M, Clarke WE, Logan A: Differential expression of fibroblast growth factor-2 and fibroblast growth factor receptor 1 in a scarring and nonscarring model of CNS injury in the rat. Eur J Neurosci 2001;13:443-456.

184 Masumura M, Murayama N, Inoue T, Ohno T: Selective induction of fibroblast growth factor receptor-1 mRNA after transient focal ischemia in the cerebral cortex of rats. Neurosci Lett 1996;213:119-122.

185 Takami K, Iwane M, Kiyota Y, Miyamoto M, Tsukuda R, Shiosaka S: Increase of basic fibroblast growth factor immunoreactivity and its mRNA level in rat brain following transient forebrain ischemia. Exp Brain Res 1992;90:1-10.

186 Agasse F, Nicoleau C, Petit J, Jaber M, Roger M, Benzakour O, Coronas V: Evidence for a major role of endogenous fibroblast growth factor-2 in apoptotic cortex-induced subventricular zone cell proliferation. Eur J Neurosci 2007;26:3036-3042.

187 Fagel DM, Ganat Y, Cheng E, Silbereis J, Ohkubo Y, Ment LR, Vaccarino FM: Fgfrl is required for cortical regeneration and repair after perinatal hypoxia. J Neurosci 2009;29:1202-1211.

188 Baldauf K, Reymann KG: Influence of EGF/ BFGF treatment on proliferation, early neurogenesis and infarct volume after transient focal ischemia. Brain Res 2005; 1056 : 158-167.

189 Ganat Y, Soni S, Chacon M, Schwartz ML, Vaccarino FM: Chronic hypoxia up-regulates fibroblast growth factor ligands in the perinatal brain and induces fibroblast growth factor-responsive radial glial cells in the sub-ependymal zone. Neuroscience 2002;112:977-991.

190 Leker RR, Soldner F, Velasco I, Gavin DK, Androutsellis-Theotokis A, McKay RDG: Long-lasting regeneration after ischemia in the cerebral cortex. Stroke 2007;38:153161.

191 Monfils M-H, Driscoll I, Kamitakahara H, Wilson B, Flynn C, Teskey GC, Kleim JA, Kolb B: FGF-2-induced cell proliferation stimulates anatomical, neurophysiological and functional recovery from neonatal motor cortex injury. Eur J Neurosci 2006;24: 739-749.

192 Vergano-Vera E, Mendez-Gomez HR, Hurtado-Chong A, Cigudosa JC, VicarioAbejon C: Fibroblast growth factor-2 increases the expression of neurogenic genes and promotes the migration and differentiation of neurons derived from transplanted neural stem/progenitor cells. Neuroscience $2009 ; 162: 39-54$. 
193 Dayer AG, Jenny B, Sauvain M-O, Potter G, Salmon P, Zgraggen E, Kanemitsu M, Gascon E, Sizonenko S, Trono D, Kiss JZ: Expression of fgf-2 in neural progenitor cells enhances their potential for cellular brain repair in the rodent cortex. Brain 2007;130: 2962-2976.

194 Doetsch F, Garcia-Verdugo JM, AlvarezBuylla A: Cellular composition and threedimensional organization of the subventricular germinal zone in the adult mammalian brain. J Neurosci 1997; 17: 5046-5061.

195 Doetsch F, Petreanu L, Caille I, Garcia-Verdugo JM, Alvarez-Buylla A: Egf converts transit-amplifying neurogenic precursors in the adult brain into multipotent stem cells. Neuron 2002;36:1021-1034.

196 Kim Y, Comte I, Szabo G, Hockberger P, Szele FG: Adult mouse subventricular zone stem and progenitor cells are sessile and epidermal growth factor receptor negatively regulates neuroblast migration. PLoS One 2009;4:e8122.

197 Reynolds BA, Weiss S: Generation of neurons and astrocytes from isolated cells of the adult mammalian central nervous system. Science 1992;255:1707-1710.
198 Tropepe V, Craig CG, Morshead CM, van der Kooy D: Transforming growth factoralpha null and senescent mice show decreased neural progenitor cell proliferation in the forebrain subependyma. J Neurosci 1997;17:7850-7859.

199 Gonzalez-Perez O, Romero-Rodriguez R, Soriano-Navarro M, Garcia-Verdugo JM, Alvarez-Buylla A: Epidermal growth factor induces the progeny of subventricular zone type $B$ cells to migrate and differentiate into oligodendrocytes. Stem Cells 2009;27: 2032-2043 (erratum published in Stem Cells 2009;27:3122).

200 Grimm I, Ullsperger SN, Zimmermann H: Nucleotides and epidermal growth factor induce parallel cytoskeletal rearrangements and migration in cultured adult murine neural stem cells. Acta Physiol 2010; 199:181-189.

201 Aguirre A, Rizvi TA, Ratner N, Gallo V: Overexpression of the epidermal growth factor receptor confers migratory properties to nonmigratory postnatal neural progenitors. J Neurosci 2005;25:11092-11106.

202 Sundholm-Peters NL, Yang HKC, Goings GE, Walker AS, Szele FG: Subventricular zone neuroblasts emigrate toward cortical lesions. J Neuropathol Exp Neurol 2005;64: 1089-1100.

203 Ninomiya M, Yamashita T, Araki N, Okano $\mathrm{H}$, Sawamoto K: Enhanced neurogenesis in the ischemic striatum following EGF-induced expansion of transit-amplifying cells in the subventricular zone. Neurosci Lett 2006;403:63-67.
204 Cooper O, Isacson O: Intrastriatal transforming growth factor alpha delivery to a model of Parkinson's disease induces proliferation and migration of endogenous adult neural progenitor cells without differentiation into dopaminergic neurons. J Neurosci 2004;24:8924-8931.

205 Fallon J, Reid S, Kinyamu R, Opole I, Opole R, Baratta J, Korc M, Endo TL, Duong A, Nguyen G, Karkehabadhi M, Twardzik D, Patel S, Loughlin S: In vivo induction of massive proliferation, directed migration, and differentiation of neural cells in the adult mammalian brain. Proc Natl Acad Sci USA 2000;97:14686-14691 (erratum published in Proc Natl Acad Sci USA 2001;98: 8157).

206 Aguirre A, Gallo V: Reduced EGFR signaling in progenitor cells of the adult subventricular zone attenuates oligodendrogenesis after demyelination. Neuron Glia Biol 2007;3:209-220.

207 Martinez R, Eller C, Viana NB, Gomes FCA: Thyroid hormone induces cerebellar neuronal migration and Bergmann glia differentiation through epidermal growth factor/mitogen-activated protein kinase pathway. Eur J Neurosci 2011;33:26-35. 